\title{
APPLICATION OF GEOSYNTETICS IN THE FUNCTION OF ENVIRONMENTAL PROTECTION
}

\author{
Петровић Марија ${ }^{1}$ \\ Симић Невена ${ }^{2}$ \\ Петронијевић Предраг ${ }^{3}$ \\ Аризановић Драган ${ }^{4}$ \\ Маринковић Дејан
}

UDK: 502,17

DOI:10.14415/konferencijaGFS2017.052

Summary: The processes of industrialization and urbanization, apart from positively reflecting on the overall progress of a society, also have the increase of communal waste as a consequence. At the same time, these processes activate a series of new possibilities when it comes to development of the environmental responsibility. Inadequate waste management leads to pollution of all the environmental media and that is why there is so much interest for action in this area. The structure of this paper is presented through the activities from the construction phase of the objects for waste acceptance - sanitary landfills. By working in several directions, geo-synthetic materials can present the answer to complex mechanisms appearing not only during the building phase but also during the exploitation. The dominant role of a geo-barrier is not limited to the protective function as it can also, to certain extent, affect the mechanical characteristics of the soil it is set on. Besides construction technology for such objects, a comparative presentation of the types of geo-barriers is given, including the possibilities and limitations during the construction and exploitation.

Кључне речи: геосинтетиџи, заштита животне средине, депоније чврстог отпада, геомембране.

\section{INTRODUCTION}

,We didn't inherit land from our fathers and grandfathers, but we borrowed it from our descendants "

Land, as an infinite semi space, represents a resource whose users constantly change, trying to hand it to their descendants without disturbing its natural processes. The environmental protection is actually a mission, whose participants change, accepting the consequences of the acts of their predesessors, nonetheless. Evolutionary development of civilization is followed by discoveries, that are the direct consequence of humans'

\footnotetext{
${ }^{1}$ Петровић Марија, студент докторских студија, Грађевински факултет Београд

${ }^{2}$ Симић Невена, студент докторских студија, Грађевински факултет Београд

${ }^{3}$ Доц др Петронијевић Предраг, Грађевински факултет Беогрда

${ }^{4}$ Доц др Аризановић Драган, Грађевински факултет Београд

5 Доц др Маринковић Дејан, Грађевински факултет Београд
} 
endeavor to adjust the nature itself to their needs. Along with the process of industrialization and other parts of development of a certain society goes the increase of waste. The term "waste" implies every material or object that appears during the production, service or any other activity, object that will no longer be used, as well as waste materials that have to be disposed from the manufacturer's and consumer's point of view [2]. Although waste is an object removed from further use, with skillful management arose the idea of the potential of the waste, as an energetic resource first of all. In that way a chance is given to materials to participate once more in the creation of the new product, now being raw material. There is always a part of that waste that cannot be further recycled. Destiny of that kind of waste is connected to the last activity in the hierarchy of waste management, permanent disposal (Pic. 1). Uncontrolled waste disposal, leads to violation of ecological circumstances through the emissions of toxic materials into the environment.

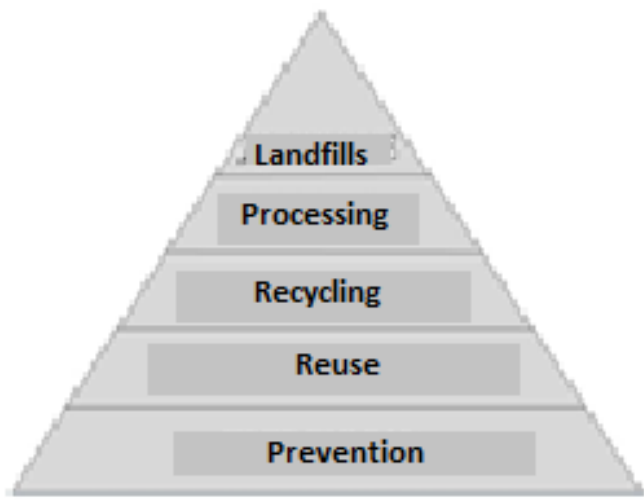

Pic 1: Hierarchy of waste management

When we talk about the amount of generated waste in the world, according to a research, we came to a number of 1,2 billion tons of municipal waste per year [4]. As for Serbia, there's $2,374,375$ tons of generated waste per year ( $0.87 \mathrm{~kg}$ waste per inhabitant)[2].

The integral waste management represents concept, aiming to minimalize the influences occurring as a products in the process of optimized system of treating waste in one country [3]. Improvement of this process is positively thought of in any society. When it comes to the strategy of waste management, it is necessary to identify main 5 activities that can be seen in Pic. 1 presented in the model of hierarchy. Linking the activities creates the positive effect, as well as ranging the activities, especially while implementing various programmes of the society .

He hierarchy concept of waste management is based on reduction of waste creation at the beginning, while trying to cut the number of the amount of resources used. This approach is the "base" of the pyramid of the chronologically tested waste. The last activity represents waste disposal on places where there are legal document to confirm it as a disposal place. Although modern approach of treating waste doesn't include the initial disposal on the landfills, certain part of the waste is permanently disposed on the landfill. The construction of landfills represents mainly used ecological method od municipal waste disposal, because modern technologies, such as incineration, reclamation etc. don't find its its base in the countries in development, like Serbia, only because the price for 
Contemporary achievements in civil engineering 21. April 2017. Subotica, SERBIA

implementation of these facilities is very high. In addition, we will talk about safe solid waste.

\section{WASTE LANDFILL}

Landfills are places where solid waste and residual materials are permanently disposed. Excluding the waste disposal on the bottom of the ocean, waste disposal on the surface is the last activity in the mission of "waste management" (See Pic. 1).

The fact that in Serbia, only $60 \%$ of the entire municipal waste is being disposed, mainly in city areas, seeks serious approach in improving the system of waste management [5]. In 1999. in the European Union the Directive of landfills was enacted, based on the USA regulations. Based on the European Directive, in Serbia, in 2010. The Statute was brought concearning waste disposal on the landfills. The Statute brings conditions an criteria for the location, technical and technological conditions for projecting, construction and the work of landfills, waste disposal on landfill, the ways and procedures of work and closure of landfill, the way of monitoring and mainteinance after the closure of. Landfill. [1]

\section{CONDITIONS FOR CONSTRUCTING LANDFILL}

Before the materials are chosen, it is necessary to take into account all conditions needed for that kind of a structure, so they have its function according to the project. These kinds of objects have a role in controlled disposal of solid waste, bearing in mind and caring for the environment. As we know there are contaminated processes happening in the landfill itself. So, it is necessary to use materials on following conditions:

- Watertightness (sealing role)

- Filtration (in the drainage system)

- Separation (isolated influence of different materials)

The core of the structure of each landfill are watertight layers. The statute defining the procedures for constructing landfill and treatment of waste, defines the importance of watertight layer. The materials used have to have watertight properties. Its main job is to prevent leakage of contaminated liquid (or gas) into the surrounding environment, i.e. preventing any contact between soil and fluid. Watertight layers are not only made of barriers, but of drainage materials. Watertight barriers prevent leakage of contaminated liquid into the surrounding environment, while the drainage system sends dangerous materials to the adequate facility, defined beforehand (pipe which drains away contaminated fluid into the reception pool).

When we talk about the function of separation two materials, we have in mind superposition of positive influences of each material. Catchword " $10 \mathrm{~kg}$ of stone, mixed with $10 \mathrm{~kg}$ od mudd, results in $20 \mathrm{~kg}$ of mudd" [6] reflects very clearly the importance of separation of materials. In order to get the projected function of the material, it is necessary to isolate it from other gradients. It isn't necessary for the material to be watertight (except in the case of fluid materials). Smaller wholes in the structure itself comparing to nominal granulate grain, are quite enough.. 

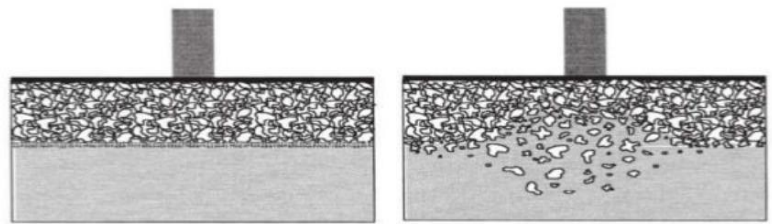

Pic 2: Mechanism of geosyntetics' effects while separation

Taking all of the above into account, we may conclude that there must be at least three types of materials in the landfill construction, to complete all the conditions. Materials themselves can be divided into two big categories: traditional and contemporary. Traditional materials are mainly natural materials such as compressed soil, clay and other similar materials. It should be noted that if sealing layer is made of only natural materials (for example clay) thickness of that material is in range of 1-5m [1]. Within artificial materials, there are different kinds of plastic foils and sealing bands. The dominant role of these materials, as the products of chemical industry, is the protection of the ground from harmful influences of disposed waste. Such foils separated two areas with different substrates and prevented leakage of liquid products of chemical reactions into the surrounding space. Longterm exposure of these bands to the sunlight, longevity, elasticity and specific weight were reduced. Contemporary materials are based on an idea of traditional materials, but with significant improvement of noted flaws. Correction of chemical structure creates materials that make a revolution in creating ecological infrastructure. Such materials are known as geosyntetics. This work deals with geosyntetics that can make a positive influence in construction of solid waste landfills.

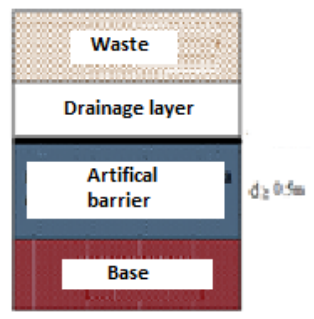

Pic. 3:

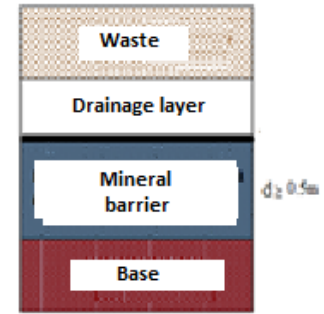

Comparison of thickness of material layers under the waste layer, applying traditional mineral barriers $=$ clay $($ left $)$ and contemporary materials $=$ geosyntetics $($ right $)$

\section{THE TECHNOLOGY OF CONSTRUCTION OF SOLID WASTE LANDFILL}

The application of geosyntetics in the construction of landfill is best analysed through the structure of card of technological process (Pic 4). Because of great number of activities, due to more precise technological overview, the card of technological process is divided into two parts: part of works until the moment when landfill is ready to receive waste materials, and part when it is necessary to "close" disposed waste and revitalize the ground (pic). The card of technological process from pic 4 is only one of the possible solutions. We will be dealing with advantages/disadvantages comparing to alternative solutions. 


\section{$5^{\text {th }}$ INTERNATIONAL OONEREENCE}

Contemporary achievements in civil engineering 21. April 2017. Subotica, SERBIA

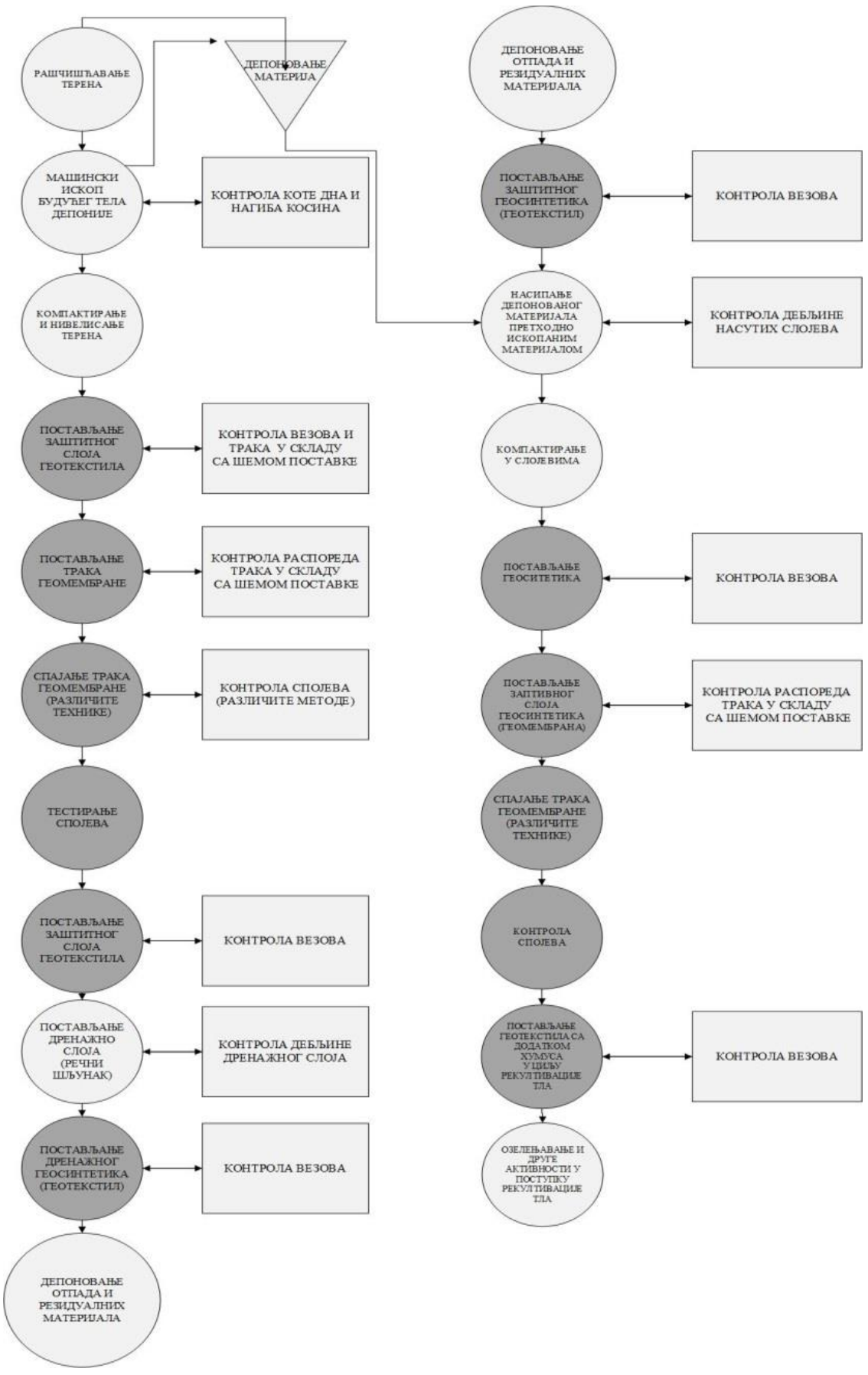

Pic 4: The card of technological process of construction solid waste landfill 
There are two categories of functions that geosyntetics have in the construction of landfills, in order to optimize and to control time and costs during the process:

- primary

- secondary

Primary activities of geosyntetics in the landfill base are functional activities, i.e. activities of main importance for functioning of system, this complex:

- $\quad$ setting sealing layers

- $\quad$ setting drainage systems

- revitalization of the ground above the landfill

Secondary activities are treated as the activities that lead to functionality of primary activities when the goals are achieved. In other words, the role of the materials used in dealing with secondary activities is protection.

System, whose goal is prevention of liquid leakage is made od two components: natural and artificial.

Natural materials that function as waterthick barrier are clay-based material. The main characteristic of these materials is swelling when in contact with liquid, and thus forming waterthick layer. Apart from clay, bentonite, sand and stone dust can be used. According to Statute for constructing landfills the mineral layer mustn't be less $0,5 \mathrm{M}$.

Artificial waterthick materials are geosyntetic barriers. The process of setting and linking geomembraneare vital in its functionality.

The most commonly used machine for stretching geomembrane is drudge. Connecting devices are being installed on the front of drudge where geomembrane roll is installed. While installing geomembrane mustn't be additionally tightened. It should only be set on te base.

Geomembranes are used for great surfaces so it is necessary to link bands of materials. Linking can be done on the spot or in factories. Factory compouds are better and more reliable, but well done links in situ may also satisfy safety coefficients. Linking should be done on the temperatures above $5^{\circ} \mathrm{C}$ and humidity mustn't bi higher than $80 \%$. Links should be oriented parallel with slopes.

In the landfill base chemical reactions happen with separation of contaminated liquid as a consequence. In order to evacuate liquid properly into reception pools it is of main importance that the drainage system functions properly. The drainage system contains drainage trench (pic below), filtration material as a filling of drainage trench (geosyntetics and incoherent grain material) and drainage pipe which accepts and evacuates water. Geosyntetics used within drainage of ground are geotextiles, geomembrane and different composites (geotextile is a necessary part of composites). On the other hand, geomembranes do not have filtration capability. They represent polymer materials in the role of waterthick barriers. Geomembranes have to prevent drained water to reach the ground. Apart from the protective function, geomembranes also have supporting function. This condition is necessary so the geomembranes can handle

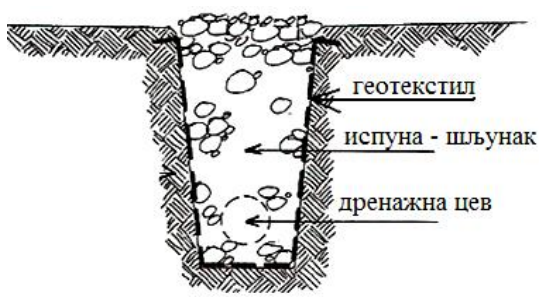


Contemporary achievements in civil engineering 21. April 2017. Subotica, SERBIA

the weight of drainage pipe and filling of drainage trench. Considerable savings are made, by using geomembrane for encasement of drainage trench. Geomembranes are used instead of concrete panel which was once used to prevent leakage of water into the ground under the trench, as well as to accept the weight of the filling. Recultivating layer ensures that soil above the landfill can be used. Materials based on geosyntetics that can be used in the process of revitalization of the soil, are actually materials rich in hummus.

\section{CONCLUSION}

Visually, geosyntetics have simple structure. Some of them are similar to cloth, and in return they deal with complicated issues. Apart from structure, it should be noted that they easily implement in construction. They are easy to maintain. They don't need complicated facilities for set up. All of these crucial aspects are talked about in detail in this work. Apart from the parameters describing the material and its function, we shouldn't neglect ecological influence of these material on the environment where they are being produced, kept and set. One of the factors, incharged for the mass application of geosyntetics is their eco suitability. Not only that geosyntetics don't harm the environment, they prevent its contamination.

\section{REFERENCES}

[1] Attachment of projecting waterthick layers of landfills - Milica Karanac, Mica Jovanovic, Eugene Timmermans, Huib Mulleneers, Marina Mihajlovic, Jovan Jovanovic

[2] Managing waste, the way of scientific research in the future - Goran Vujic, Dusan Milovanovic

[3] The influence of waste on inhabitants in urban zones - contribution to causeconsequence relations - Hristina Stevanovic Carapina, Andjelka Mihajlov

[4] Babic B et all. (1995), Geosyntetics in civil engineering, Croatian society of civil engineers, Zagreb

[5] Integrated solid waste management: engineering principles and management issues Tchobanoglous, G.;Theisen, H.;Vigil, S. 